\title{
BUDAPESTTŐL BERLINIG - INTERDISZCIPLINÁRIS KALANDOZÁSOK. IZSÁK ÉVA GEOGRÁFUS SZÜLETÉSNAPJÁRA
}

Egy ünnepi kötet összeállítása és egy tudományos, és mégis személyes köszöntő megszervezése komplex feladat, amelyhez értő szem és finom érzék kell. Mindezt teljesítették a Festschriftet írók, szerkesztők és a rendezők, akik egyben a geográfia, a társadalomföldrajz, a városszociológia és a társtudományok (szociológia, közgazdaságtan, történettudomány, pszichológia stb.) jeles képviselői. Tárgyukról mindannyian interdiszciplináris szemlélettel és módszerrel írtak, de nem hagyták figyelmen kívül az ünnepelt, Izsák Éva 50. születésnapját mint kitüntetett alkalmat.

Milyennek ismerjük Izsák Évát? Elbizonytalanodunk a válaszadáskor. Éppúgy, mint Az emberi kalandban Hankiss Elemér Homo sapiense (1997), aki az istent faggatja, mondaná meg, mi lesz vele ebben a világban? „....az emberek hozzáláttak, hogy felépítsék a maguk világát egy idegen világon belül. A védelmező falak, házak és városok, szerszámok és fegyverek, mítoszok, vallások és kompromisszumok világát. Sok száz éves, archetipikus élménye az emberiségnek az a sokk és a félelem, hogy nincs itthon ebben a világban, idegen ebben a világban, hogy törékeny és gyenge teremtés, hogy ezernyi veszélynek és szenvedésnek van kitéve.”

Hasonló útkeresésben találjuk Izsák Évát nemcsak e jeles napon, hanem a tudományos és a mindennapi életben egyaránt. Ezért is tartom telitalálatnak a születésnapi kötet fö- és alcímét, ahol az olvasó önkéntelenül kiegészíti saját élményeivel a meghatározó világvárosok névsorát, és az interdiszciplináris kalandozásokét. A szerkesztők, Berki Márton és Halász Levente találékonyságát dicséri, hogy szakítanak a történettudomány által erőteljesen birtokolt kalandozás fogalom historizálásával, és kitágítják a gondolkodásunkat, s egyúttal orientálnak a korszerü városszociológia megismerésére.

Mitől interdiszciplináris a tanulmánykötet?

A szerzők több tudományterület (müvészettörténet, szociológia szociálpszichológia stb.) jeles képviselői, akik mégis ismerik azt a közös nyelvet, amelynek lényege: az élhető környezet és élvezhető kultúra együttes megjelenésének biztosítása és minőségének fenntartása egy adott, épített településen.

A tematikus szerkesztői elv orientál ugyan, de hozzárendelődnek személyes élményeink. Így érthető, miért lett a nyitó tanulmányok egyike a big data alkalmazása a társadalomföldrajzban, amely jelenleg a társadalomtudományi kutatásokban kitüntetett szereppel bír (Baji, 15-28.).

Kutatói érdeklődésem alapján az életmódra, életminőségre, a jóllétre, a szegregáció különböző formáira figyeltem föl. A tömeg- és szubkultúrára reflektáló írások egyrészt érdekesek szaktudományi szempontból, másrészt szimbolikus 
jelentéssel bírnak. Élvezettel vezettettem magam Czibula Katalin (39-50.) elemzési útján, aki a budapesti városkép alakulásának történetét operett- és slágerszövegek értelmezésén keresztül mutatja be. Nemcsak Fényes Szabolcs-Pártos Jenő-Szécsény Mihály máig népszerủ operettslágerét idézi a szerző (Budapest, Budapest, te csodás!), ahol Budapest „...mint ideális élettér jelenik meg az új ideális ember számára. A szocialista nagyváros nyüzsgő világa az új szocialista embertípus éltető közege mind a munka, mind a szórakozás tereként jelenik meg..." (Czibula, 40.).

A 60-as évek nagyvárosi élményéhez a fények (Breitner János-Farkas Imre: Gyönyörü igy este Budapest, 1959), a hidak, lakótelepek építése is hozzátartozik, $\mathrm{s}$ benne a mindennapi élet, az ún. kisember csetlése-botlása - szemben a hatalom folyamatos ellenőrzésével, az ideológia direkt utasításaival. A dalokban, filmekben a városi attitüdök is megjelennek, nemcsak pozitív értelemben: „,...a korai kelés, rohanás, tömegközlekedés, zaj” (Czibula, 43.). És mégis: „Nékem csak Budapest kell,/Hol az ember kora reggel szívesen kel,/Mert imádom forró szerelemmel.” (Fényes Szabolcs-Romhányi József: Nékem csak Budapest kell, a Napfény a jégen címü filmből, 1961.)

De ezeket a tanulmányokat a kultúra fogalmának széles értelmében vizsgálva is fontosnak tartjuk, hasonlóképpen a szegregáció, a szegénység, az életminőség változásának a lokális térbeli vizsgálataival (Berki Márton, Czibula Katalin, Csébi Márk, Dúll Adrea, Probáld Ferenc, S. Nagy Katalin). De új jelenségek is körvonalazódnak, mint a zsugorodás problémája, az urbanizáció jelenkori kihívásai (Halász, 121-136.).

Unikális Probáld Ferenc (201-210.) munkája, aki a bélyegeken látható városképekről, illetve alkotóikról ad érzékletes bemutatást.

Módszertani szempontból izgalmas Dúll Andea (85-118.) tanulmánya, miközben fogalmi tisztázásra is vállalkozik az eredményorientált település-/várostervezésben, szemlélteti azt a komplex eljárást, amelyet sikeresen alkalmaz kutatótársaival együtt. Feltárják a helyi lakosok önérvényesítési képességeinek szintjét, ezek összefüggéseit a környezetészlelésükkel és szerepeik percepciójával, kommunikációjával stb. (Dúll, 85.).

Az utazások emlékeit felidéző kalandozások is többes jelentésűek: jól kitapinthatóak a szerzők élményei, pozitív attitüdjei a témákkal kapcsolatban, és utalnak Izsák Éva utazási szenvedélyére és érdeklődésére is, egyben felcsigázzák az olvasó kíváncsiságát a saját élmény megszerzésére. (Például Siskáné Szilasi Renáta, 217-228.)

Az ünnepelt Izsák Éva maga is nagyvároslakó, kutató, ezért a nagyvárosi létröl, az ottani jól- és rosszlétről, a lakosság egészségügyi helyzetéről és kilátásairól stb. szóló esszék (S. Nagy Katalin, Szirmai Viktória, Kázmér Miklós, Sebastian Kinder) jelzik, mennyi izgalmas területe van a városkutatásnak interdiszciplináris megközelítésből. 
A (nagy)városok átalakulása mellett - legyen szó Berlinről vagy Budapestről szó van ebben a kötetben a kisvárosok helyzetéről, a lokalitás-globalitás paradigmáiról éppúgy, mint az egyenlötlenségekről a fejlesztés, a képzés, az egészségügy, a bevándorlás-kivándorlás aspektusából. Így nyer igazolást a kötet alcíme: Interdiszciplináris kalandozások.

A felsoroltak közül a korlátozott terjedelem miatt csak egy tanulmányra reflektálnék most. Szirmai Viktória és munkatársai dolgozatukban impozáns kutatási kérdéseket tesznek föl, mint például „....mi történik a hasonló politikai, társadalmi, gazdasági berendezkedésủ és jellegü kelet- és közép-európai térségekben, közte a Kárpát-medencei régiókban? Vagy: tapasztalható-e a felzárkózás... vagy épp diverzifikálódás? [...] megfigyelhetőek-e a hasonló koncentrációs folyamatok itt is, mint a fejlett nyugati modellek esetében. Tapasztalható-e felzárkózás, illetve közeledés a vizsgált különböző országok és régiók adatai között?” (Szirmai, 230.)

Hangsúlyosak a budapesti bulinegyedről írottak, részben mủvelődés- és müvészettörténeti okoknál fogva (S. Nagy Katalin), részben a lokalitás-globalitás fogalom változása miatt, de az aktuális problémák okán, amikor a belvárosi lakhatási feltételek és a turizmus érdekei ütköznek, esetenként elementáris erővel.

S. Nagy Katalin konklúziójából idézek: „A mai nyitott utcaművészet hangsúlyos jelenléte napjaink korszellemének terméke, tele aktuálpolitikai mozzanattal, múlttal és jelennel, transzformációkkal és felszabadultsággal, lelkesedéssel, iróniával, allegorizációkkal, zsúfolva formai és tartalmi gazdagsággal, ellentmondásossággal.” (S. Nagy, 215.)

Az előző állításomat igazolják azok a dolgozatok, ahol a szerzők a kultúra részeként értelmezik a társadalomföldrajzi, településfejlesztési, átalakítási kérdéseket. Épp itt jelentkeznek azok a fiatal kutatók írásaikkal, akik Izsák Éva doktoranduszai voltak (Baji Péter [2016], Bányai Borbála [2015], Berki Márton [2014], Halász Levente [2019], Váradi Zsuzsanna [2012], Uzzoli Annamária [2004]). Olyan szellemiséget visznek tovább, amely szigorúan szervezett, de dinamikus terepmunkára, részt vevő megfigyelésre, folyamatos szakirodalmi müveltség szerzésre, $\mathrm{s}$ végső soron önálló kérdések megfogalmazására késztette őket, mivel korábban is ilyen inspirációkat kaptak Izsák tanárnőtől mint témavezetőtől.

Megérintett és emlékeket idézett S. Nagy Katalin és Sebastian Kinder írása a nagyvárosok arculatával kapcsolatban. Közép-európaiként adódik a folyamatos összehasonlítási igény a városlátogatások alkalmával, mivé lettek a Monarchia nagyvárosai: Bécs, Pozsony, Prága (S. Nagy, 214.), hogyan változott Berlin szocreál utcaképe lenyügöző világvárosivá, és miként ,adta meg magát” az átalakulásnak, például a street artnak a középkor óta virágzó iskolaváros: Tübingen.

Lelket melengetőek a személyes köszöntők (Losonczi Ágnes, F. Várkonyi Zsuzsa, Nemes Nagy József, Tóth Kriszta), hiszen a születésnap a legfontosabb szervező közege, lényege ennek a kötetnek. Ízelítőül néhány figyelemfelkeltő, értékelő vélemény Izsák Éva munkásságáról: 
„De bármily különlegesnek tünik is specializált világunkban, hogy valaki a geográfia mellett a társadalomtudományokkal is szorosabb kapcsolatba akar lépni, végső soron ez volna a világon a legtermészetesebb dolog... Saját szakmai tapasztalatom is azt mutatta, hogy a terepkutatások esetében a »Mit kutatunk?« mellett a »Hol kutatunk? « volt a leginkább meghatározó kérdések egyike... mindketten értelemszerü »segédeszközként« használjuk tudományos érvelésünkben az irodalmi műveket, képzőművészeti alkotásokat, azt a világról szóló mélyebb tudást, amely a művészetekben ragadható meg." (Losonczi, 196.)

„[Izsák] Éva a választott kutatói és oktatói pálya, a tudományterület iránt megingathatatlanul elkötelezett ember. Azok közé tartozik, aki társadalomföldrajzosként nemcsak szakított a geográfia egységében értéket látó szemlélettel... minden témakör mögött a természeti és társadalmi folyamatok, a földtudomány és a tértudomány összefüggéseiről szólnak.” (Nemes Nagy, 197-200.)

„Jössz-mész a világban, ezer dolog érdekel... állandóan gyűjtöd az információkat a világ jelenségeiről, sok tucat barátoddal... tartod... a kapcsolatot, tanítasz és tanulsz... miközben tőled jó néhány fontos képességet »elvont « az élet, szellemi és lelki síkon óriási többletet küldött.” (F. Várkonyi, 119.)

És nem maradhat el a költészet dicsérete sem: „Budapest éjjel nyári álom/huzatos lépcsők ablakfények/ idegen házak sokszor látott/ filmből az arcok visszatérnek/ Se földön már se égen/sose lesz újra régen" (Tóth, 251.).

Bár az ünnepi írásokból válaszokat kaphatunk Izsák Éva személyiségjegyeire, barátságaira, kötődéseire, mégis, a saját élményü kapcsolat fontosságára hívnám föl a figyelmet, s arra, hogy - tekintsünk el a közhelyes fogalom használatától felelősek vagyunk a barátságaink ápolásáért, hiszen „Hová mennél el hogyha mennél/hova is szöknél önmagadtól/üres utcákon jár az emlék/csenevész fák közt barangol/ Se földön már se égen/sose lesz újra régen" (Tóth, 251.).

(Berki Márton - Halász Levente szerkesztök: Budapesttöl Berlinig-interdiszciplináris kalandozások: tiszteletkötet Izsák Éva születésnapja alkalmából. Budapest: ELTE Földrajz-és Földrajztudományi Intézet, 2019, 219 o. [Fehérvár Travel Kft., 1783-3/2018/FEKUTSRAT, az EMMI támogatásával])

Tibori Timea 